\title{
Potentially pathogenic bacteria isolated from diverse habitats in Spitsbergen, Svalbard
}

\author{
Diana C. Mogrovejo-Arias ${ }^{1}$ [D · Florian H. H. Brill ${ }^{1}$ - Dirk Wagner ${ }^{2,3}$
}

Received: 26 April 2019 / Accepted: 11 February 2020 / Published online: 26 February 2020

(c) The Author(s) 2020

\begin{abstract}
The Arctic ecosystem, a reservoir of genetic microbial diversity, represents a virtually unlimited source of microorganisms that could interact with human beings. Despite continuous exploration of Arctic habitats and description of their microbial communities, bacterial phenotypes commonly associated with pathogenicity, such as hemolytic activity, have rarely been reported. In this study, samples of snow, fresh and marine water, soil, and sediment from several habitats in the Arctic archipelago of Svalbard were collected during Summer, 2017. Bacterial isolates were obtained after incubation on oligotrophic media at different temperatures and their hemolytic potential was assessed on sheep blood agar plates. Partial $(\alpha)$ or true $(\beta)$ hemolysis was observed in 32 out of 78 bacterial species. Genes expressing cytolytic compounds, such as hemolysins, likely increase the general fitness of the producing microorganisms and confer a competitive advantage over the availability of nutrients in natural habitats. In environmental species, the nutrient-acquisition function of these compounds presumably precedes their function as toxins for mammalian erythrocytes. However, in the light of global warming, the presence of hemolytic bacteria in Arctic environments highlights the possible risks associated with these microorganisms in the event of habitat melting/destruction, ecosystem transition, and re-colonization.
\end{abstract}

Keywords Arctic $\cdot$ Svalbard $\cdot$ Hemolysins $\cdot$ Climate change $\cdot$ Pathogens $\cdot$ Virulence

\section{Introduction}

Even though cold environments have long been regarded as extreme due to low temperatures, low water and nutrient availability and high levels of UV radiation, they are actively inhabited by a variety of microorganisms (Maccario et al. 2015). Ecosystems such as tundra, permafrost, and glaciers are regarded as biomes, harboring species from the

Electronic supplementary material The online version of this article (https://doi.org/10.1007/s12665-020-8853-4) contains supplementary material, which is available to authorized users.

Diana C. Mogrovejo-Arias

Diana.Mogrovejo@brillhygiene.com;

dcmogrovejo@yahoo.com

1 Dr. Brill + Partner GmbH Institut für Hygiene und Mikrobiologie, Stiegstück 34, 22339 Hamburg, Germany

2 Section Geomicrobiology, GFZ German Research Center for Geosciences, Telegrafenberg C-425, 14473 Potsdam, Germany

3 Institute of Geosciences, University of Potsdam, Karl-Liebknecht-Str. 24-25, 14476 Potsdam, Germany
Bacteria, Archaea, and Eukarya domains (Wagner 2008; Kirby et al. 2012) and constitute major pools of genomic diversity (Edwards 2015). The Arctic, spanning more than 7 million $\mathrm{km}^{2}$ across regions of Alaska, Canada, Northern Europe, Greenland, Iceland, and Russia (Kirby et al. 2012), has great potential for research focused on the diversity of microbial communities as well as their interactions with the environment. However, this ecosystem is highly sensitive to perturbations and environmental changes (Davidson et al. 2011). Due to the Arctic's low adaptative capacity (Gitay et al. 2002), the consequences of environmental disturbances are usually amplified (Doney et al. 2012; Kirby et al. 2012). As a result of climate change, the annual mean temperature in the Arctic has increased twice as much as in other parts of the world (Davidson et al. 2011; Kirby et al. 2012; MateosRivera et al. 2016) altering a variety of habitats and raising concerns about diversity loss and the possible (re)emergence of diseases (Kurane 2010; Davidson et al. 2011; Reich et al. 2012; Altizer et al. 2013; Wang et al. 2016).

Stressful conditions brought about by a changing climate can heavily influence competition within bacterial communities and might even play a key role in the 
expression of virulence genes (Mekalanos 1992; Livermore 2003; D'Amico et al. 2006). Bacterial species can produce extracellular proteins, such as enterotoxins, coagulases and cytolysins, aimed at reducing the competition in their environment or at inflicting damage in neighboring cells to gain access to their nutrients (Tomita and Kamio 1997; Madigan et al. 2012; Harwood et al. 2018). Among these toxins, hemolysins are of special interest. Since their activity is more easily observed in mammalian erythrocytes, they are frequently referred to as hemolysins, even though red blood cells are rarely their only target in vivo (Tomita and Kamio 1997). Secreted by a variety of organisms, hemolysins are responsible for damaging cellular membranes, causing cell lysis, destroying neighboring tissues, and are considered a major virulence determinant in infection models of laboratory animals (Bhakdi et al. 1994; Bayley 1997; Tomita and Kamio 1997; Madigan et al. 2012).

Bacteria can exhibit three different types of hemolytic activity (Buxton 2005): Beta ( $\beta$ ) hemolysis, when the toxin causes the complete lysis of the red blood cells. Often referred to as true lysis, it manifests as a clear, transparent area in the blood agar cultures; alpha $(\alpha)$ hemolysis, when lysis does not occur but the hemoglobin of the red blood cells is reduced to methemoglobin and a brown/green colored area can be observed in blood agar cultures; gamma $(\gamma)$ hemolysis, or non-hemolysis, when no damage to the cells is caused and no change in the agar plate is observed.

The distinction between $\alpha$ and $\beta$ hemolysis is of relevance in some areas, such as the assessment of the safety of probiotics (Jeon et al. 2017), but it is not generally made in other settings because both types of hemolysis are usually considered a virulence determinant and one of the many phenotypes studied to determine the clinical relevance of the species and/or strains (Bayley 1997; Ramachandran 2013). For this reason, in this study, isolates with either $\alpha$-hemolytic or $\beta$-hemolytic activity are referred to as hemolytic.

The expression of hemolysins has infrequently been assessed in bacterial isolates from environmental samples (Bevivino et al. 2002; González-Rodríguez et al. 2007; Albarral et al. 2016) and much less is known about the hemolytic activity of Arctic species. As warming global temperatures are favoring the geographic expansion of pathogens and increasing the risk of human exposure to infectious disease (Revich et al. 2012; IPCC 2014), it is increasingly important to study the presence of potential pathogens in Arctic environments and the expression of virulent phenotypes.

For this purpose, bacteria from several habitats in Spitzbergen, the biggest island of the Svalbard archipelago (Norway) in the High Arctic were isolated and taxonomically classified. We tested whether or not the isolates displayed hemolytic activity in an effort to highlight the possible implications of their presence in the context of public health, habitat alteration, and destruction caused by climate change.

\section{Materials and methods}

\section{Sampling sites}

Samples of snow, glacier forefield soil, sediment, glacier meltwater, pond, and marine water were collected in triplicate from various sites in the High Arctic island of Spitsbergen, Svalbard (Norwegian territory) during summer of 2017 (Fig. 1; Table 1). During the sampling process, sterile nitrile gloves were used and sampling was carried out facing the wind. For the samples of snow and soil, $5 \mathrm{~cm}$ of the surface were discarded and a disinfected shovel or sterile spoon was used to store the sample in sterile plastic bags (Whirl-Pak bags; Nasco). Water and sediment samples were collected using sterile collection bottles and a Niskin sampler. All samples were frozen at $-20{ }^{\circ} \mathrm{C}$ until processing in the lab.

\section{Cultivation and isolation of bacteria}

Samples were thawed overnight at $4{ }^{\circ} \mathrm{C}$ prior to culture. All samples were plated on oligotrophic media R2A (Oxoid) in duplicate. Serial dilutions were used for all sample types and the plates were incubated at 5,17 , and $37{ }^{\circ} \mathrm{C}$ for as long as 4 months, in sterile plastic bags to conserve the humidity of the agar media. Negative control plates were prepared with sterile water frozen prior to culturing and thawed following the same procedure as the samples. Two control plates were streaked for each testing temperate and incubated in the same conditions and for the same duration as the samples. Liquid and enrichment cultures were not used.

Morphologically different colonies were selected as soon as they became visible on the plates, and transferred successively to new R2A plates to obtain pure cultures. Axenic cultures were confirmed by Gram staining and DNA sequencing as described below.

\section{S rRNA gene sequencing and phylogenetic characterization}

Genomic DNA was extracted from the isolates using a bacterial DNA extraction kit (OMEGA BIO-TEK) and the 16S rRNA gene was amplified via PCR using universal primers 8F (5'-AGA-GTT-TGA-TCC-TGG-CTC-AG-3') and 1541R (5'-AAG-GAG-GTG-ATC-CAG-CCG-CA-3') (Tam et al 2015) and ready-to-use PCR reaction mix (MangoMix, Bioline). Two negative controls using nuclease-free water were prepared for each DNA extraction as well as PCR reaction. The PCR conditions were initial denaturation at $94{ }^{\circ} \mathrm{C}$ for 2 min, followed by 30 cycles of denaturation at $94^{\circ} \mathrm{C}$ for 
A

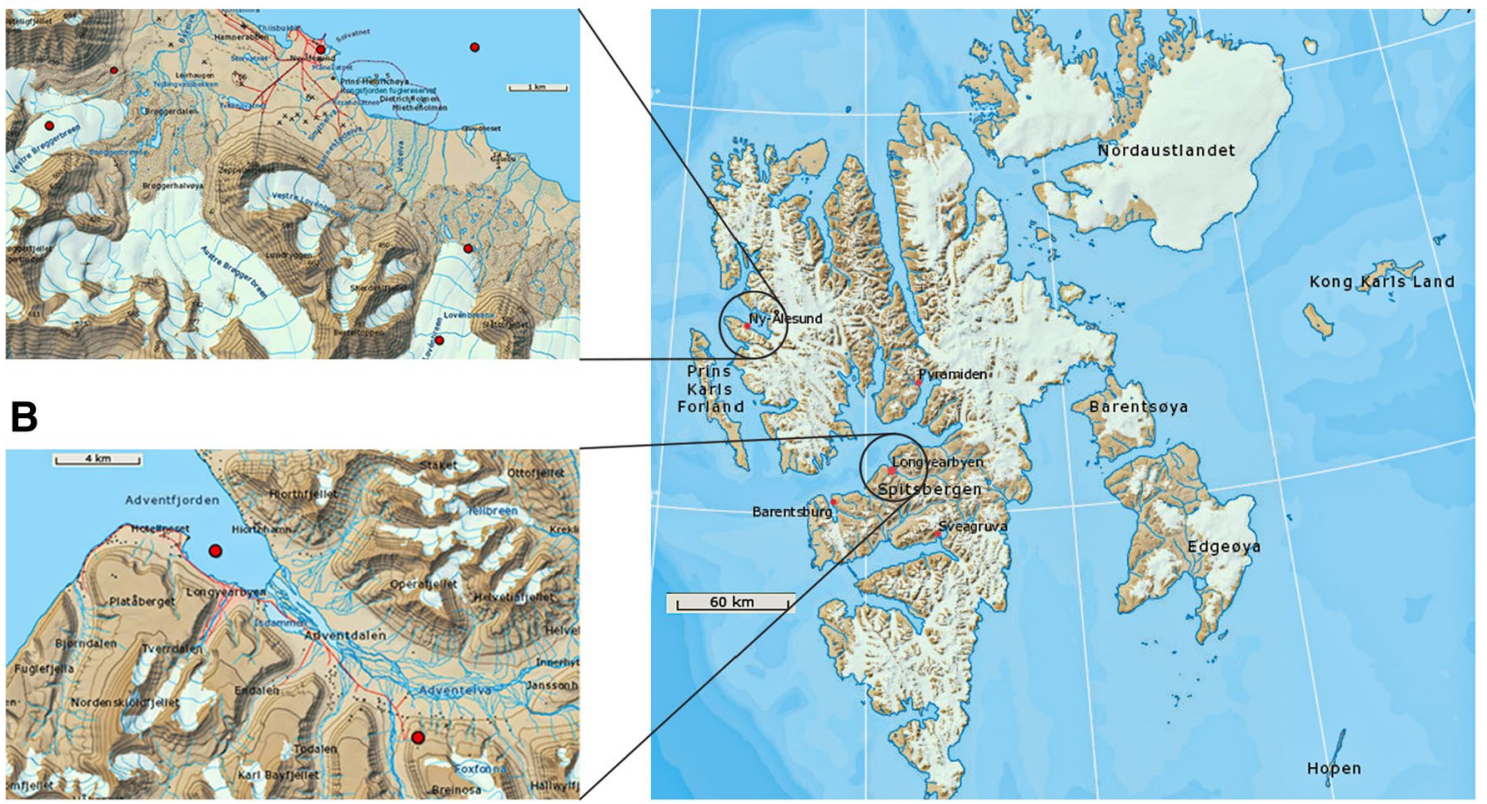

Fig. 1 Sampling sites in the Svalbard archipelago, Norway. The samples were taken from locations on the island of Spitsbergen: a sampling sites around the area of Ny-Ålesund and $\mathbf{b}$ sampling sites around the area of Longyearbyen (Map adapted from TopoSvalbard, courtesy of the Norwegian Polar Institute, available at: https://topos valbard.npolar.no/)

Table 1 Sampling locations for this study and colony forming units (CFU) for all samples after incubation for 4 months

\begin{tabular}{|c|c|c|c|c|c|}
\hline Sample collected & Site description & Site coordinates & $\mathrm{CFU}$ at $5^{\circ} \mathrm{C}$ & $\mathrm{CFU}$ at $17^{\circ} \mathrm{C}$ & $\mathrm{CFU}$ at $37^{\circ} \mathrm{C}$ \\
\hline \multirow[t]{3}{*}{ Snow } & Seasonal pond up the valley of Adventdalen & $78^{\circ} 09^{\prime} 24^{\prime \prime} \mathrm{N} 16^{\circ} 01^{\prime} 59^{\prime \prime} \mathrm{E}$ & $1 \times 10^{3}$ & $1 \times 10^{3}$ & $2 \times 10^{3}$ \\
\hline & Midtre Lovénbreen (ML) glacier & $78^{\circ} 53^{\prime} 08^{\prime \prime} \mathrm{N} 12^{\circ} 02^{\prime} 44^{\prime \prime} \mathrm{E}$ & $2 \times 10^{2}$ & $6 \times 10^{1}$ & 0 \\
\hline & Vestre Brøggerbreen (VB) glacier & $78^{\circ} 54^{\prime} 42^{\prime \prime} \mathrm{N} 11^{\circ} 43^{\prime} 42^{\prime \prime} \mathrm{E}$ & 0 & 0 & 0 \\
\hline \multirow[t]{4}{*}{ Water } & Meltwater from ML glacier & $78^{\circ} 53^{\prime} 25^{\prime \prime} \mathrm{N} 12^{\circ} 03^{\prime} 15^{\prime \prime} \mathrm{E}$ & $6 \times 10^{1}$ & $8 \times 10^{1}$ & $4 \times 10^{1}$ \\
\hline & Water from a pond near the town of Ny-Ålesund & $78^{\circ} 55^{\prime} 34^{\prime \prime} \mathrm{N} 11^{\circ} 56^{\prime} 21^{\prime \prime} \mathrm{E}$ & $2 \times 10^{3}$ & $6 \times 10^{3}$ & 0 \\
\hline & Seawater from Adventfjorden & $78^{\circ} 14^{\prime} 27^{\prime \prime} \mathrm{N} 15^{\circ} 36^{\prime} 59^{\prime \prime} \mathrm{E}$ & $3 \times 10^{3}$ & $9 \times 10^{3}$ & $1 \times 10^{4}$ \\
\hline & Seawater from Kongsfjorden & $78^{\circ} 55^{\prime} 33^{\prime \prime} \mathrm{N} 12^{\circ} 02^{\prime} 29^{\prime \prime} \mathrm{E}$ & $1 \times 10^{2}$ & $2 \times 10^{2}$ & $3 \times 10^{1}$ \\
\hline \multirow[t]{2}{*}{ Soil } & Forefield from ML glacier & $78^{\circ} 53^{\prime} 54^{\prime \prime} \mathrm{N} 12^{\circ} 03^{\prime} 59^{\prime \prime} \mathrm{E}$ & $2 \times 10^{5}$ & $1 \times 10^{8}$ & $5 \times 10^{3}$ \\
\hline & Forefield from VB glacier & $78^{\circ} 55^{\prime} 20^{\prime \prime} \mathrm{N} 11^{\circ} 46^{\prime} 38^{\prime \prime} \mathrm{E}$ & $1 \times 10^{5}$ & $8 \times 10^{7}$ & $1 \times 10^{4}$ \\
\hline \multirow[t]{2}{*}{ Sediment } & marine sediment from Adventfjorden & $78^{\circ} 14^{\prime} 27^{\prime \prime} \mathrm{N} 15^{\circ} 36^{\prime} 59^{\prime \prime} \mathrm{E}$ & $2 \times 10^{5}$ & $2 \times 10^{5}$ & $2 \times 10^{4}$ \\
\hline & Pond sediment near the town of Ny-Ålesund & $78^{\circ} 55^{\prime} 34^{\prime \prime} \mathrm{N} 11^{\circ} 56^{\prime} 21^{\prime \prime} \mathrm{E}$ & $9 \times 10^{4}$ & $2 \times 10^{8}$ & $2 \times 10^{5}$ \\
\hline
\end{tabular}

Colony forming unit $(\mathrm{CFU})$ counts given in $\mathrm{CFU} / \mathrm{ml}$ for all samples except soil and sediment, which are given as CFU/g

$20 \mathrm{~s}$, annealing at $60^{\circ} \mathrm{C}$ for $25 \mathrm{~s}$, extension at $70{ }^{\circ} \mathrm{C}$ for $90 \mathrm{~s}$, and a final extension step at $72{ }^{\circ} \mathrm{C}$ for $5 \mathrm{~min}$.

Amplicons were visualized on $2 \%$ agarose gels and those reactions with the expected size (approx. $1500 \mathrm{bp}$ ) were purified (Monarch cleanup kit, New England Biolabs) and Sanger sequenced (Seqlab-Microsynth GmbH, Germany).

Using the BLASTN interface, ${ }^{1}$ the DNA sequences were aligned and taxonomically assigned to characterized

\footnotetext{
$\overline{1}$ Available at: https://blast.ncbi.nlm.nih.gov/Blast.cgi.
}

reference taxa (16S ribosomal bacteria database). The $16 \mathrm{~S}$ rDNA sequences obtained in this study were deposited in the NCBI GenBank nucleotide database. The accession numbers assigned are MH714605-MH714685 (Table S1).

\section{Hemolytic activity of the isolates}

Isolates were inoculated on Columbia agar with sheep blood (Oxoid). The media consisted of peptone $\left(23 \mathrm{~g} \mathrm{l}^{-1}\right)$, starch $\left(1 \mathrm{~g} \mathrm{l}^{-1}\right)$, sodium chloride $\left(5 \mathrm{~g} \mathrm{l}^{-1}\right)$, and agar $\left(10 \mathrm{~g} \mathrm{l}^{-1}\right)$ with $5 \%$ sterile sheep blood added after autoclave sterilization. 
Table 2 Types of hemolysis, by sample type, observed in the bacterial isolates

\begin{tabular}{lllll}
\hline Sample type & Phyla & $\alpha$ (Partial) hemolysis & $\beta$ (Complete) hemolysis & $\gamma$ (Non) hemolysis \\
\hline Snow & Actinobacteria & & & S20, S28, S34 \\
& Firmicutes & & S44, N83 & S22, S31, S54, N84, N91 \\
Water & Actinobacteria & An34, S10, S32, S60, N106 & S23b, S58 & S5, N54, N85, N93 \\
& Firmicutes & & & N87, N92 \\
& Proteobacteria & & N18, N28, N41, N42 & N72 \\
Soil & Actinobacteria & & & N7, N9, N10a, N17, N57b, N81b \\
& Bacteroidetes & & N2, N34 & N15, N30, N30b, N43, N78 \\
& Firmicutes & & N60, N71 & An21, An24, S16, S25, S72, \\
& Proteobacteria & & & S73, S81, S87 \\
Actinobacteria & S26 S24 & N36a & S65 \\
& Bacteroidetes & & S7, S71, N23, N24, N39 & S15, S77, S90, N36 \\
& Firmicutes & An58, S27b, S70, N58 & & S35, S67, S84, S88, N96 \\
\hline
\end{tabular}

The bacteria were streaked across the plate to observe individual colonies' phenotypes and a section of the same plate without streak was inoculated via needle puncture to search for oxygen-labile hemolysins. The plates were incubated for $18 \mathrm{~h}$ at room temperature (approx. $25^{\circ} \mathrm{C}$ ).

An isolate was considered $\alpha$-hemolytic when the colonies caused a green or brown discoloration in the surrounding medium, $\beta$-hemolytic when true lysis of the red blood cells resulted in a clear, transparent zone surrounding the colonies and gamma $\gamma$-hemolytic or non-hemolytic, when there was no reaction in the surrounding medium (Buxton 2005).

\section{Results}

\section{Bacterial cultures and phylogenetic characterization}

After 4 months of cultivation of samples from Spitzbergen in oligotrophic media (R2A) at different temperatures $(5,17$, and $37^{\circ} \mathrm{C}$ ), colony forming units (CFU) were counted on all plates. Samples of snow had the lowest viable count (up to $2 \times 10^{3} \mathrm{CFU} \mathrm{ml}^{-1}$ ) in comparison to samples of soil (up to $1 \times 10^{8} \mathrm{CFU} \mathrm{g}^{-1}$ ) or sediment (up to $2 \times 10^{8} \mathrm{CFU} \mathrm{g}^{-1}$ ), which had the highest (Table 1).

A total of 78 unique isolates were obtained and about $83 \%$ of these were from incubation temperatures of $17^{\circ} \mathrm{C}$ or $37^{\circ} \mathrm{C}$ (Table S1). Gram-positive genera accounted for $59 / 78$ isolates. Nutrient-rich samples, i.e., sediment and soil, yielded the majority of isolates $(55 / 78)$, followed by seawater (12/78), snow (6/78), melt water (4/78), and finally pond water $(1 / 78)$.
The 16S rRNA gene sequencing revealed that the 78 unique isolates (Table S1) belong to the phyla Actinobacteria (32 isolates), Firmicutes (28), Proteobacteria (15), and Bacteroidetes (3), representing a total of 37 different genera. The most abundant genera within each phylum were: 5 Arthrobacter spp. (Actinobacteria), 12 Bacillus spp. (Firmicutes) and 7 Pseudomonas spp. (Proteobacteria). In contrast, the three Bacteroidetes species belong to three different genera, i.e., Pedobacter, Flavobacterium, and Algoriphagus (Table S1).

When compared to their closest neighbors in the GenBank database, three isolates had 16S rDNA sequence identities lower than 97\% (Table S1) possibly indicating that they correspond to new species: An21 (944nt, 93\% identity to Propioniciclava tarda, GenBank accession number NR_112669.1), N24 (945nt, 83\% identity to Bacillus clausii, GenBank accession number NR_026140.1), and N54 (838nt, 94\% identity to Psychrobacillus psychrodurans, GenBank accession number NR_025409.1).

\section{Hemolytic activity of the isolates}

Results of the incubation of pure cultures on blood agar are shown in Table 2, while examples of the observed phenotypes are shown in Fig. 2. After incubation, 32/78 isolates were hemolytic, representing the aforementioned four phyla and out of which 28/32 corresponded to Gram-positive genera. Nutrient-rich samples, i.e., soil and sediment, harbored more hemolytic bacteria (23/32) compared to other sample types such as snow (2/32) or water (7/32). Gamma (nonhemolytic) isolates, 46/78, were distributed among all four phyla and all sample types (Table 2). 
Fig. 2 Examples of hemolytic phenotypes observed in Arctic isolates inoculated on Columbia agar supplemented with sheep blood and incubated at room temperature $\left(25^{\circ} \mathrm{C}\right)$ for $18 \mathrm{~h}$. Isolates shown are $\mathrm{S} 73 / \mathrm{N} 9$ for $\gamma$-hemolysis, S70/N58 for $\alpha$-hemolysis, and S44/N34 for $\beta$-hemolysis
Gamma hemolysis

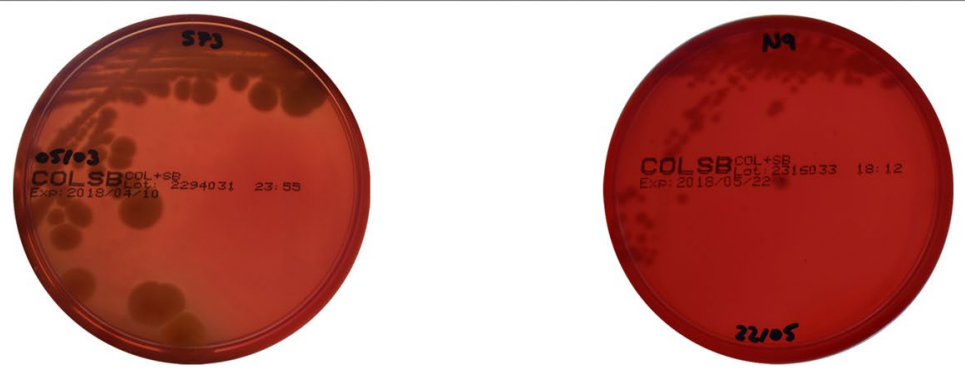

Alpha hemolysis

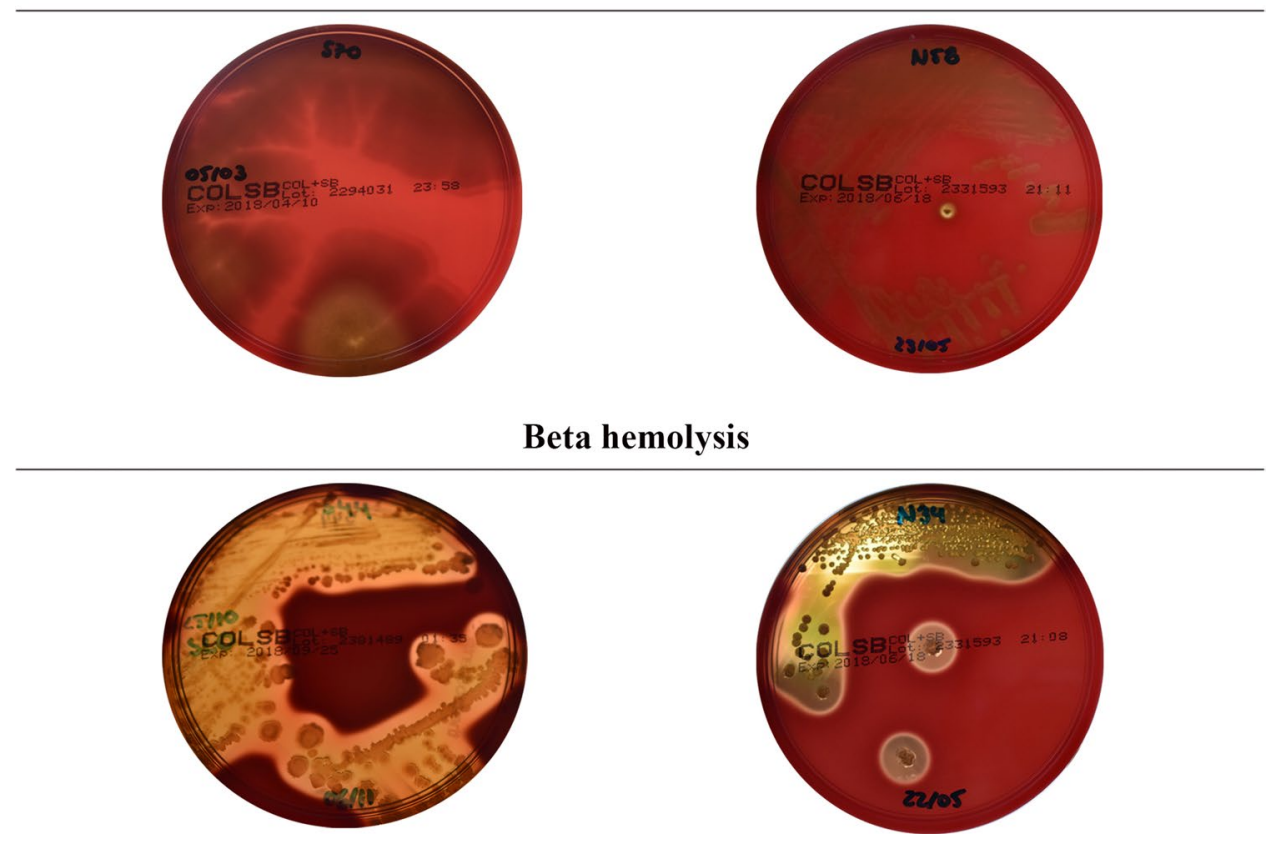

\section{Discussion}

To gain insight into the presence and diversity of environmental bacteria that display potential pathogenic phenotypes, samples from the Artic archipelago of Svalbard were cultured. Altogether, 78 genetically diverse isolates of 37 different genera were obtained and their hemolytic activity was assessed.

In accordance to what has been reported before in Arctic environments (Amato et al. 2007), more isolates were obtained from nutrient-rich samples like soil or sediment (55/78), which are known to have notably higher numbers of viable cells compared to other sample types such as snow or seawater (Amato et al. 2007; Hansen et al. 2007; Kirby et al. 2012).

The isolates showed growth at temperatures well above those they endure in the environments from which they were obtained. In fact, $65 / 78$ isolates were obtained from incubation temperatures of 17 or $37{ }^{\circ} \mathrm{C}$, an indication of their psychrotolerant and mesophilic nature and confirming that psychrophilic and psychrotolerant microorganisms inhabit the same environments but the latter are more abundant (Moyer and Morita 2007; De Maayer et al. 2014). Sequencing of the $16 \mathrm{~S}$ rDNA gene revealed that the isolates belonged to four phyla usually found in Arctic environments, namely Actinobacteria, Bacteroidetes, Firmicutes, and Proteobacteria (Amato et al. 2007; Maccario et al. 2014; Wang et al. 2016).

Bacterial species isolated from polar habitats which display hemolytic phenotypes are virtually undocumented. In this study, however, we observed an important number of bacteria displaying hemolytic activity (32/78 isolates). Gram-positive species are the most common producers of cytolytic toxins (Masignani et al. 2006; Ramachandran 2013), which we confirmed by finding 28 Gram-positive hemolytic species vs. only four Gram-negative ones (Table S1).

Some of the closest neighbors of the isolates we obtained have been found to produce a variety of cytolytic and cytotoxic compounds, among others, pore-forming compounds 
such hemolysin I, II, and III, hemolysin BL as well as other non-specific cytolytic compounds such as surfactin. This is the case for isolates S7, S44, S70, S71, N34, closely related to species of the Bacillus genus: B. cereus (Ramarao and Sanchis 2013), B. methylotrophicus (Harwood et al. 2018), B. wiedmannii (Miller et al. 2016), B. licheniformis (Harwood et al. 2018) and B. amyloliquefaciens (Phelps and McKillip 2002). Under stressful conditions, Bacillus spp. can release compounds that cause the lysis of the majority of the population to release the nutrients and resources needed for sporulating cells (Harwood et al. 2018). Other members of the Firmicutes, i.e. Carnobacterium spp., and Enterococcus spp. have also been reported as hemolytic (Vancanneyt et al. 2002; De Vos et al. 2009), confirming our observations for isolates An58 and S27b.

Actinobacteria species are generally regarded as an abundant source of metabolites such as antibiotics, antioxidants, and hemolytic as well as anti-hemolytic compounds (Goodfellow et al. 2009; Suthindhiran and Kannabiran 2009; Pang et al. 2016). We observed members of the genera Micromonospora, Streptomyces, and Oerskovia (isolates S3, S10, N18, $\mathrm{N} 28$, and N41) that exhibited hemolytic activity, supporting previous reports of species in these genera that might be considered opportunistic pathogens (McNeil and Brown 1994; Pang et al. 2016; Mohammadipanah and Momenilandi 2018; Takahashi and Nakashima 2018).

Furthermore, we found isolates that display hemolytic activity for which the genus and/or closely related species had been previously described as non-hemolytic. For instance, Funke et al. (1997) reported that Brevibacteria are non-hemolytic (Funke et al. 1997). However, isolate S24 (Brevibacterium spp.) was beta-hemolytic in our assays. Similarly, Bacillus clausii isolates had been previously reported as non-hemolytic (Funke et al. 1997; Jeon et al. 2017), whereas in our assays, Bacillus spp. isolates N23 and N24 possess beta-hemolytic activity.

Isolates S8, S23b, S26, and S60, which were identified as Microbacterium spp., displayed hemolytic activity. Even though reference to hemolytic phenotypes is rare, members of the Microbacterium genus are increasingly isolated from clinical samples and are considered opportunistic human pathogens (Goodfellow et al. 2009).

Finally, to the best of our knowledge, the closest neighbors to isolates An34, S32, S58, N2, N36a, N39, N42, N60, N61, N71, N83, and N106, which are, respectively, Leifsonia kafniensis, Tessaracoccus flavescens, Salinibacterium amurskyense, Exiguobacterium undae, Pedobacter nyackensis, Carnobacterium funditum, Streptomyces fulvissimus, Pseudomonas helmanticensis, Psychrobacter nivimaris, Pseudomonas lurida, Bacillus idriensis, and Salinibacterium xinjiangense, had not been previously assessed for hemolytic activity but some reports exist of these species or other members of their genera with pathogenic phenotypes (Ostroff et al. 1990; Ko et al. 2006; Ülbegi-mohyla et al. 2009; Leisner et al. 2012; Tayabali et al. 2015; Chen et al. 2017; Milivojevic et al. 2018).

When cytotoxins from environmental species are seen occurring across many sample types, and bacterial genera, as it's shown here, it can be inferred that the production of toxins constitutes part of the many mechanisms devised to survive in severe environmental conditions. In fact, the expression of this phenotype is aimed at reducing surrounding microbial competition or at obtaining scarce nutrients (mainly iron contained in neighboring cells or tissues) and increasing the competitiveness and survival rates of the species (Harding et al. 2011; Harwood et al. 2018). Importantly, while the production of hemolysins is often considered a virulence determinant when assessing the relevance of pathogens in clinical settings (Bhakdi et al. 1994), it has been noted that in environmental species, the nutrient acquisition and competition functions presumably precede their virulent/toxic functions in potential hosts (Falkow 2004). Microbial communities evolve under the influence of external abiotic factors as well as the selective pressure of the surrounding microorganisms. New genotypes and phenotypes are the result of the mutually exerted selection and in turn, they shape the functional properties of the community as a whole (Vayssier-Taussat et al. 2014).

Interestingly, the adaptations allowing survival in cold environments could also allow colonization of human-associated environments (D'Amico et al. 2006). Since several virulence properties of bacterial species, such as hemolytic toxins, are expressed while transitioning between environments, e.g. snow to melt water to sediment, and constitute a survival strategy (Mekalanos 1992), their expression could be used as an indicator of pathogenicity. In fact, the pathogenic potential of an organism is clearly related to the toxins it produces and hemolysins represent one the most potent and versatile tool with which invading microbes damage the host cells (Bhakdi et al. 1994). Since hemolytic activity is rarely regarded as a housekeeping function (Mekalanos 1992; Masignani et al. 2006), the different habitats of Svalbard may be considered as potentially harboring pathogenic bacterial species.

Due to its remote location, geological and biological history, the Svalbard archipelago in the High Arctic is a prime natural system for studying the effects of environmental disturbances brought about by climate change (Isaksen et al. 2007; Park et al. 2011). Warming temperatures in polar areas will likely favor the expansion of forest ecosystems and agricultural activities which will be followed by expanding human settlements and consequently, human-associated pathogens (Gitay et al. 2002; Revich et al. 2012) Altered climatic conditions directly affect disease patterns (Epstein 2001) and research addressing the sensitivity of endemic 
microorganisms and their adaptation mechanisms is becoming of greater importance (Kirby et al. 2012; Reich et al. 2012; Boetius et al. 2015).

It is important to consider the risks associated with potentially virulent environmental bacteria and the possibility of their dispersal to new habitats (Harding et al. 2011) through the destruction/disappearance of natural barriers (melting glaciers, thawing permafrost) acting as ecological filters (Park et al. 2011; Underwood 2014) as well as increased animal migrations (Allen et al. 2010) and a marked increase in human activities near the poles (Vayssier-Taussat et al. 2014; Edwards 2015).

The results of this study represent, to the best of our knowledge, the first observations of hemolytic phenotypes in culturable bacteria from Arctic environmental samples. The expression of hemolysins is likely an adaptation mechanism used to survive the stressful conditions of the polar habitats. Moreover, the presence of this potentially virulent phenotype in natural environments provides valuable information about the evolution of clinically relevant species and opportunistic pathogens. Finally, our research contributes further knowledge useful to predict and prepare responses to the countless consequences and global alterations brought about by a drastically changing climate.

Acknowledgements This work was supported by the European Union's Horizon 2020 research and innovation programme [Marie SkłodowskaCurie Grant Agreement 'Microarctic' No. 675546]. The authors wish to thank Dr. L. Pellizzari (GFZ-Potsdam) for her helpful comments on the manuscript.

Author contributions DMA carried out the sampling, performed the experiments and wrote the manuscript with input from all co-authors. FB and DW supervised the project and contributed to the interpretation of the results and valuable discussion.

\section{Compliance with ethical standards}

Conflict of interest FB is Managing Director of Dr. Brill + Partner $\mathrm{GmbH}$. DMA was employed by Dr. Brill + Partner $\mathrm{GmbH}$ as part of a research network (European Union's Horizon 2020 research and innovation programme, Marie Skłodowska-Curie Grant agreement No 675546) and declares no conflict of interest. DW declares no competing interests.

Open Access This article is licensed under a Creative Commons Attribution 4.0 International License, which permits use, sharing, adaptation, distribution and reproduction in any medium or format, as long as you give appropriate credit to the original author(s) and the source, provide a link to the Creative Commons licence, and indicate if changes were made. The images or other third party material in this article are included in the article's Creative Commons licence, unless indicated otherwise in a credit line to the material. If material is not included in the article's Creative Commons licence and your intended use is not permitted by statutory regulation or exceeds the permitted use, you will need to obtain permission directly from the copyright holder. To view a copy of this licence, visit http://creativecommons.org/licenses/by/4.0/.

\section{References}

Albarral V, Sanglas A, Palau M, Miñana-Galbis D, Fusté MC (2016) Potential pathogenicity of Aeromonas hydrophila complex strains isolated from clinical, food, and environmental sources. Can J Microbiol 62(4):296-306. https://doi.org/10.1139/cjm-2015-0466

Allen HK, Donato J, Wang HH, Cloud-Hansen KA, Davies J, Handelsman J (2010) Call of the wild: antibiotic resistance genes in natural environments. Nat Rev Microbiol 8(4):251-259. https:// doi.org/10.1038/nrmicro2312

Altizer S, Ostfeld RS, Johnson PTJ, Kutz S, Harvell CD (2013) Climate change and infectious diseases: from evidence to a predictive framework. Science 341(6145):514-519. https://doi.org/10.1126/ science. 1239401

Amato P, Hennebelle R, Magand O, Sancelme M, Delort AM, Barbante C, Ferrari C (2007) Bacterial characterization of the snow cover at Spitzberg. Svalbard FEMS Microbiol Ecol 59(2):255-264. https ://doi.org/10.1111/j.1574-6941.2006.00198.x

Bayley H (1997) Toxin structure: part of a hole? Curr Biol 7(12):R763R767. https://doi.org/10.1016/S0960-9822(06)00399-X

Bevivino A, Dalmastri C, Tabacchioni S, Chiarini L, Belli ML, Piana S, Manno G (2002) Burkholderia cepacia complex bacteria from clinical and environmental sources in Italy: Genomovar status and distribution of traits related to virulence and transmissibility. J Clin Microbiol 40(3):846-851. https://doi.org/10.1128/ JCM.40.3.846-851.2002

Bhakdi S, Grimminger F, Suttorp N, Walmrath D, Seeger W (1994) Proteinaceous bacterial toxins and pathogenesis of sepsis syndrome and septic shock: the unknown connection. Med Microbiol Immunol 183(6):343-344. https://doi.org/10.1007/BF00196684

Boetius A, Anesio AM, Deming JW, Mikucki JA, Rapp JZ (2015) Microbial ecology of the cryosphere: sea ice and glacial habitats. Nat Rev Microbiol 13(11):677-690. https://doi.org/10.1038/nrmic ro3522

Buxton R (2005) Blood agar plates and hemolysis protocols. https:// www.asm.org/getattachment/7ec0de2b-bb16-4f6e-ba07-2aea2 5a43e76/protocol-2885.pdf. Accessed 19 Dec 2018

Chen X, Wang L, Zhou J, Wu H, Li D, Cui Y, Lu B (2017) Exiguobacterium $\mathrm{sp}$. A1b / GX59 isolated from a patient with communityacquired pneumonia and bacteremia: genomic characterization and literature review. BMC Infect Dis 17(508):1-7. https://doi. org/10.1186/s12879-017-2616-1

D’Amico S, Collins T, Marx J-CC, Feller G, Gerday C (2006) Psychrophilic microorganisms: challenges for life. EMBO Rep 7(4):385389. https://doi.org/10.1038/sj.embor.7400662

Davidson R, Simard M, Kutz SJ, Kapel CMO, Hamnes IS, Robertson LJ (2011) Arctic parasitology: why should we care? Trends Parasitol 27(6):238-244. https://doi.org/10.1016/j.pt.2011.02.001

De Maayer P, Anderson D, Cary C, Cowan DA (2014) Some like it cold: understanding the survival strategies of psychrophiles. EMBO Rep 15(5):508-517. https://doi.org/10.1002/embr.20133 8170

De Vos P, Garrity G, Jones D, Krieg N, Ludwig W, Rainey F, Schleifer K, Whitman W (eds) (2009) Bergey's manual of systematic bacteriology. Volume three, The Firmicutes. 2nd edn. Springer, New York. https://doi.org/10.1007/978-0-387-68489-5

Doney SC, Ruckelshaus M, Emmett Duffy J, Barry JP, Chan F, English CA, Talley LD (2012) Climate change impacts on marine ecosystems. Ann Rev Mar Sci 4(1):11-37. https://doi.org/10.1146/annur ev-marine-041911-111611

Edwards A (2015) Coming in from the cold: potential microbial threats from the terrestrial cryosphere. Front Earth Sci 3(April):10-13. https://doi.org/10.3389/feart.2015.00012 
Epstein PR (2001) Climate change and emerging infectious diseases. Microbes Infect 3(9):747-754. https://doi.org/10.1016/S1286 $-4579(01) 01429-0$

Falkow S (2004) Molecular Koch's postulates applied to bacterial pathogenicity - a personal recollection 15 years later. Nat Rev Microbiol 2(1):67-72. https://doi.org/10.1038/nrmicro799

Funke G, Von Graevenitz A, Clarridge JE, Bernard KA (1997) Clinical microbiology of Coryneform bacteria. Clin Microbiol Rev 10(1):125-159. https://doi.org/10.1128/CMR.10.1.125

Gitay H, Suárez A, Watson R, Dokken D (2002) Climate change and biodiversity. IPCC Technical Paper V - April 2002. IPCC, Geneva, Switzerland

González-Rodríguez N, Santos JA, Otero A, García-López ML (2007) Cell-associated hemolytic activity in environmental strains of Plesiomonas shigelloides expressing cell-free, iron-influenced extracellular hemolysin. J Food Prot 70(4):885-890. https://doi. org/10.4315/0362-028X-70.4.885

Goodfellow M, Kampfer P, Busse H-J, Trujillo M, Suzuki K, Ludwig W, Whitman W (eds) (2009) Bergey's manual of systematic bacteriology. Volume 5, Parts A and B, The Actinobacteria. 2nd edn. Springer, New York. https://doi.org/10.1007/978-0-387-68233-4

Hansen AA, Herbert RA, Mikkelsen K, Jensen LL, Kristoffersen T, Tiedje JM, Finster KW (2007) Viability, diversity and composition of the bacterial community in a high Arctic permafrost soil from Spitsbergen, Northern Norway. Environ Microbiol 9(11):2870 2884. https://doi.org/10.1111/j.1462-2920.2007.01403.x

Harding T, Jungblut AD, Lovejoy C, Vincent WF (2011) Microbes in high arctic snow and implications for the cold biosphere. Appl Environ Microbiol 77(10):3234-3243. https://doi.org/10.1128/ AEM.02611-10

Harwood CR, Mouillon JM, Pohl S, Arnau J (2018) Secondary metabolite production and the safety of industrially important members of the Bacillus subtilis group. FEMS Microbiol Rev 42(6):721-738. https://doi.org/10.1093/femsre/fuy028

Intergovernmental Panel on Climate Change IPCC (2014) Climate Change 2014: Impacts, Adaptation, and Vulnerability. In: Barros VR, Field CB, Dokken DJ, Mastrandrea MD, Mach KJ, Bilir TE, Chatterjee M, Ebi KL, Estrada YO, Genova RC, Girma B, Kissel ES, Levy AN, MacCracken S, Mastrandrea PR, White LL (eds) Part B: regional aspects. Contribution of working group II to the fifth assessment report of the intergovernmental panel on climate change. Cambridge University Press, Cambridge, United Kingdom and New York, NY, USA, p 688

Isaksen K, Benestad RE, Harris C, Sollid JL (2007) Recent extreme near-surface permafrost temperatures on Svalbard in relation to future climate scenarios. Geophys Res Lett 34(17):1-5. https:// doi.org/10.1029/2007GL031002

Jeon HL, Lee NK, Yang SJ, Kim WS, Paik HD (2017) Probiotic characterization of Bacillus subtilis P223 isolated from kimchi. Food Sci Biotechnol 26(6):1641-1648. https://doi.org/10.1007/s1006 8-017-0148-5

Kirby BM, Easton S, Tuffin IM, Cowan DA (2012) Bacterial diversity in polar habitats. In: Miller RV, Whyte LG (eds) Polar microbiology: life in a deep freeze. ASM Press, Washington, DC, p 30. https ://doi.org/10.1086/675033

Ko KS, Oh WS, Lee MY, Lee JH, Lee H, Peck KR, Song JH (2006) Bacillus infantis sp. nov. and Bacillus idriensis sp. nov., isolated from a patient with neonatal sepsis. Int J Syst Evol Microbiol 56(11):2541-2544. https://doi.org/10.1099/ijs.0.64213-0

Kurane I (2010) The effect of global warming on infectious diseases. Public Health Res Perspect 1(1):4-9. https://doi.org/10.1016/j. phrp.2010.12.004

Leisner JJ, Hansen MA, Larsen MH, Hansen L, Ingmer H, Sørensen SJ (2012) The genome sequence of the lactic acid bacterium, Carnobacterium maltaromaticum ATCC 35586 encodes potential virulence factors. Int J Food Microbiol 152(3):107-115. https:// doi.org/10.1016/j.ijfoodmicro.2011.05.012

Livermore DM (2003) Bacterial resistance: origins, epidemiology, and impact. Bact Resist 36(September):11-23. https://doi. org/10.1086/344654

Maccario L, Vogel TM, Larose C (2014) Potential drivers of microbial community structure and function in Arctic spring snow. Front Microbiol 5(AUG):1-11. https://doi.org/10.3389/fmicb .2014 .00413

Maccario L, Sanguino L, Vogel TM, Larose C (2015) Snow and ice ecosystems: not so extreme. Res Microbiol 166(10):782-795. https://doi.org/10.1016/j.resmic.2015.09.002

Madigan MT, Martinko J, Stahl D, Clarck D (2012) Brock biology of microorganisms, 13th edn. Pearson Higher Education, San Francisco

Masignani V, Pizza M, Rappuoli R (2006) Bacterial Toxins. In: Dworkin M, Falkow S, Rosenberg E, Schleifer KH, Stackebrandt E (eds) The prokaryotes. 3rd edn. Springer, New York, NY. https:// doi.org/10.1007/0-387-30742-7_28

Mateos-Rivera A, Yde JC, Wilson B, Finster KW, Reigstad LJ, Øvreås $\mathrm{L}$ (2016) The effect of temperature change on the microbial diversity and community structure along the chronosequence of the sub-arctic glacier forefield of Styggedalsbreen (Norway). FEMS Microbiol Ecol 92(4):1-13. https://doi.org/10.1093/femsec/fiw038

McNeil MM, Brown JM (1994) The medically important aerobic actinomycetes: epidemiology and microbiology. Clin Microbiol Rev 7(3):357-417. https://doi.org/10.1128/CMR.7.3.357

Mekalanos JJ (1992) Environmental signals controlling expression of virulence determinants in bacteria. J Bacteriol 174(1):1-7. https ://doi.org/10.1128/jb.174.1.1-7.1992

Milivojevic D, Šumonja N, Medić S, Pavic A, Moric I, Vasiljevic B, Nikodinovic-Runic J (2018) Biofilm-forming ability and infection potential of Pseudomonas aeruginosa strains isolated from animals and humans. Pathog Dis 76(4):1-14. https://doi.org/10.1093/ femspd/fty041

Miller RA, Beno SM, Kent DJ, Carroll LM, Martin NH, Boor KJ, Kovac J (2016) Bacillus wiedmannii sp. nov., a psychrotolerant and cytotoxic Bacillus cereus group species isolated from dairy foods and dairy environments. Int J Syst Evol Microbiol 66(11):4744-4753. https://doi.org/10.1099/ijsem.0.001421

Mohammadipanah F, Momenilandi M (2018) Potential of rare actinomycetes in the production of metabolites against multiple oxidant agents. Pharm Biol 56(1):51-59. https://doi.org/10.1080/13880 209.2017.1417451

Moyer CL, Morita RY (2007) Psychrophiles and psychrotrophs. In: Encyclopedia of life sciences. Wiley, New York. https://doi. org/10.1002/9780470015902.a0000402.pub2

Ostroff RM, Vasil AI, Vasil ML (1990) Molecular comparison of a nonhemolytic and a hemolytic phospholipase C from Pseudomonas aeruginosa. J Bacteriol 172(10):5915-5923. https:// doi.org/10.1128/jb.172.10.5915-5923.1990

Pang X, Zhao J, Fang X, Liu H, Zhang Y, Cen S, Yu L (2016) Surfactin derivatives from Micromonospora sp. CPCC 202787 and their anti-HIV activities. J Antibiot 1:1-4. https://doi.org/10.1038/ ja.2016.63

Park SJ, Park BJ, Jung MY, Kim SJ, Chae JC, Roh Y, Rhee SK (2011) Influence of deglaciation on microbial communities in marine sediments off the coast of Svalbard. Arct Circ Microb Ecol 62(3):537-548. https://doi.org/10.1007/s00248-011-9860-5

Phelps RJ, McKillip JL (2002) Enterotoxin production in natural isolates of Bacillaceae outside the Bacillus cereus group. Appl Environ Microbiol 68(6):3147-3151. https://doi.org/10.1128/ AEM.68.6.3147-3151.2002 
Ramachandran G (2013) Gram-positive and gram-negative bacterial toxins in sepsis: a brief review. Virulence 5(1):213-218. https:// doi.org/10.4161/viru. 27024

Ramarao N, Sanchis V (2013) The pore-forming haemolysins of Bacillus cereus: a review. Toxins 5(6):7492-7502. https://doi. org/10.3390/toxins5061119

Reich PB, Tilman D, Isbell F, Mueller K, Hobbie SE, Flynn DFB, Eisenhauer N (2012) Impacts of biodiversity loss escalate through time as redundancy fades. Science 336(May):589-592. https://doi. org/10.1126/science.1217909

Revich B, Tokarevich N, Parkinson AJ (2012) Climate change and zoonotic infections in the Russian Arctic. Int J Circumpolar Health 71(6):18792. https://doi.org/10.3402/ijch.v71i0.18792

Suthindhiran K, Kannabiran K (2009) Hemolytic activity of Streptomyces VITSDK1 spp. isolated from marine sediments in Southern India. Journal de Mycologie Médicale 19:77-86. https://doi. org/10.1016/j.mycmed.2009.01.001

Takahashi Y, Nakashima T (2018) Actinomycetes, an inexhaustible source of naturally occurring antibiotics. Antibiotics 7(2):45. https ://doi.org/10.3390/antibiotics7020045

Tam HK, Wong CMVL, Yong ST, Blamey J, González M (2015) Multiple-antibiotic-resistant bacteria from the maritime Antarctic. Polar Biol 38(8):1129-1141. https://doi.org/10.1007/s0030 0-015-1671-6

Tayabali AF, Coleman G, Nguyen KC (2015) Virulence attributes and host response assays for determining pathogenic potential of Pseudomonas strains used in biotechnology. PLoS ONE 10(11):1-17. https://doi.org/10.1371/journal.pone.0143604

Tomita T, Kamio Y (1997) Molecular biology of the pore-forming cytolysins from Staphylococcus aureus, alpha- and gamma-hemolysins and leukocidin. Biosci Biotechnol Biochem 61(4):565-572. https://doi.org/10.1271/bbb.61.565

Ülbegi-mohyla H, Hassan AA, Kanbar T, Alber J, Lämmler C, Prengerberninghoff E (2009) Synergistic and antagonistic hemolytic activities of bacteria of genus Arcanobacterium and CAMP-like hemolysis of Arcanobacterium phocae and Arcanobacterium haemolyticum with Psychrobacter phenylpyruvicus. Res Vet Sci 87(2):186-188. https://doi.org/10.1016/j.rvsc.2009.01.008

Underwood E (2014) Melting arctic ice releases deadly seal parasite. https://www.sciencemag.org/news/2014/02/melting-arctic-icereleases-deadly-seal-parasite. Accessed 9 Feb 2017

Vancanneyt M, Lombardi A, Andrighetto C, Knijff E, Torriani S, Franz CMAP, Holzapfel WH (2002) Intraspecies genomic groups in Enterococcus faecium and their correlation with origin and pathogenicity. Appl Environ Microbiol 68(3):1381-1391. https ://doi.org/10.1128/AEM.68.3.1381-1391.2002

Vayssier-Taussat M, Albina E, Citti C, Cosson J-F, Jacques M-A, Lebrun M-H, Candresse T (2014) Shifting the paradigm from pathogens to pathobiome: new concepts in the light of meta-omics. Front Cell Infect Microbiol 4(March):1-7. https://doi.org/10.3389/ fcimb.2014.00029

Wagner D (2008) Microbial Communities and processes in arctic permafrost environments. In: Dion P, Nautiyal C (eds) Microbiology of extreme soils. Springer, Berlin, Heidelerg, pp 133-154. https:// doi.org/10.1007/978-3-540-74231-9_7

Wang NF, Zhang T, Yang X, Wang S, Yu Y, Dong LL, Ye Zang J (2016) Diversity and composition of bacterial community in soils and lake sediments from an arctic lake area. Front Microbiol 7(Jul):1-9. https://doi.org/10.3389/fmicb.2016.01170

Publisher's Note Springer Nature remains neutral with regard to jurisdictional claims in published maps and institutional affiliations. 